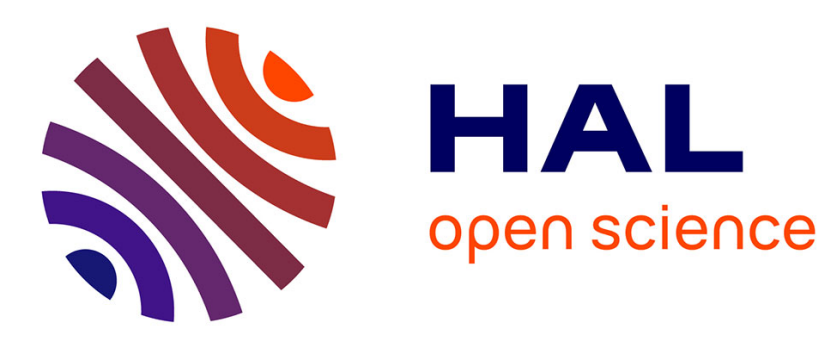

\title{
The dynamic indentation of a finite elastic plate
}

\author{
W. Madigosky, H. Überall
}

\section{To cite this version:}

W. Madigosky, H. Überall. The dynamic indentation of a finite elastic plate. Journal de Physique IV

Proceedings, 1994, 04 (C5), pp.C5-825-C5-828. 10.1051/jp4:19945178 . jpa-00252859

\section{HAL Id: jpa-00252859 https://hal.science/jpa-00252859}

Submitted on 1 Jan 1994

HAL is a multi-disciplinary open access archive for the deposit and dissemination of scientific research documents, whether they are published or not. The documents may come from teaching and research institutions in France or abroad, or from public or private research centers.
L'archive ouverte pluridisciplinaire HAL, est destinée au dépôt et à la diffusion de documents scientifiques de niveau recherche, publiés ou non, émanant des établissements d'enseignement et de recherche français ou étrangers, des laboratoires publics ou privés. 


\title{
The dynamic indentation of a finite elastic plate
}

\author{
W. MADIGOSKY and H. ÜBERALL
}

NSWC, White Oak, 10901 New Hampshire Avenue, Silver Spring, MD 20903-5640, U.S.A.

" Department of Physics, Catholic University of America, Washington, DC 20064, U.S.A.

\begin{abstract}
The Shore hardness test has been widely used and has become the standard for characterizing materials in the rubber and plastics industries. The obtained hardness scale values, ASTM or IRHD, are often related to the static elastic properties of rubber like-materials. Recently, progress on the problem of obtaining dynamic viscoelastic properties has been made through the use of an oscillating spherical indentor and modeling the measured input impedance by the radiation impedance of a radiating sphere. When the sphere radius is small, such that $k a<<1$ for longitudinal waves, then the measured shear modulus and loss factor is in good agreement with that found using other dynamic methods such as the DMTA. This model is appropriate only for relatively soft materials or very thick hard materials where the thickness of the material can be ignored. The object of the current work is to extend the methodology to layers of finite thickness. The problem is studied under the assumptions of linear lasticity and the condition that there is perfect adhesion between the indentor and the elastic layer. The method of solution that is adopted will be described and as such it constitutes the first serious attempt to solve an elastodynamic boundary value problem of this type.
\end{abstract}

\section{INTRODUCTION}

The standard durometer has been used to measure the static "hardness" or resistance of materials to indentation. In this test, a metal ball or an indentor is forced into a viscoelastic material, generally in the form of a plane flat slab specimen. The amount of penetration, or the indentation depth $h$, is related to the static Young's modulus $E$ and Poisson ratio $v$ of the viscoelastic material, to the force (load) $F$ on the sphere, and the size of the indentor. From these relations $[1,2]$, and the measurement of $F$ and $h$, one can determine $E$ and $v$ of the test object.

To our knowledge, an equivalent satisfactory dynamical model in which the indentation force is (periodically) time dependent has not been 
developed analytically. Related studies refer to a vertical time dependent point force acting on the surface of a uniform half space [3], or to a conical or wedge-shaped indentor moving into an elastic half space [4]. Empirical models have been developed for the interaction of transducers placed in contact with a viscoelastic slab to excite shear and compressional waves in the material. H. E. von Gierke et al. [5], e.g., have produced such a model to examine the acoustic properties of living tissue. They assume the transducer behaves as a spherical radiator whose diameter equals that of the cylindrical transducers used in his experiments. In this model, the radiation impedance of the vibrating sphere is related to the complex dynamical shear and compressional moduli of the material. This model, under certain approximations, can be used to infer the dynamic Young's modulus, E', and loss factor, $\delta$. To perform these measurements, the amplitude of the driving force and acceleration of the transducer which is in contact with the material are measured.

In an experimental study by Madigosky et al. [6], the validity and applicability of this model was examined by comparing the predicted results for $E^{\prime}$ and $\delta$ to those obtained by more conventional methods, such as developed by Madigosky and Lee [7], or other type of dynamic mechanical testing apparatus such as the dynamic mechanical thermal analyzer (DMTA) [8]. The goal of the study was to develop a model and simple apparatus which will allow a dynamical measurement of $E^{\prime}$ and $\delta$ of a viscoelastic material in a manufacturing environment. Table I shows the results of that study for Young's modulus E' and shear loss factor $\delta$ of Nitrile Rubber, with measurements of $F / *$ where $x$ is the acceleration of the test sphere, interpreted by von Gierke's model [5] (we shall refer to this as the Dynamic Durometer Method), as compared to the results of the DMTA method, indicating fairly good agreement between the two types of measurements.

\section{Table I. Comparison of Results on Nitrile Rubber}

\begin{tabular}{llcll} 
& \multicolumn{2}{c}{ Dynamic Durometer Method } & \multicolumn{2}{c}{ DMTA Method } \\
F $(\mathrm{Hz})$ & E $(\mathrm{MPa})$ & Loss Factor & E (MPa) & Loss Factor \\
50 & 4.3 & 0.3 & 7.5 & 0.2 \\
100 & 5.3 & 0.47 & 7.7 & 0.25 \\
200 & 7.0 & 0.34 & 7.9 & 0.3 \\
300 & 7.5 & 0.31 & 8.5 & 0.33 \\
400 & 7.8 & 0.25 & 8.9 & 0.35 \\
500 & 8.1 & 0.27 & 9.5 & 0.4
\end{tabular}

\section{THEORY}

The model of von Gierke [5] is based on a calculation by Oestreicher [9] in which the displacement field $\vec{s}$ of a rigid oscillating sphere of radius $a$, imbedded in an unbounded viscoelastic medium, is obtained in the form $\vec{s}=\vec{s}_{1}+\vec{s}_{2}$, where $\vec{s}_{1}$ is the compressional field (time dependence $\exp i \omega t)$ :

$$
\overrightarrow{\mathrm{s}}_{1}=-\mathrm{A}_{1} \vec{\nabla}\left[\mathrm{xh}_{1}{ }^{(2)}(\mathrm{kr}) / \mathrm{kr}\right],
$$

and $\vec{S}_{2}$ the shear field

$$
\vec{s}_{2}=B_{1}\left[2 h_{0}{ }^{(2)}(h r) \vec{\nabla} \mathrm{x}-\mathrm{h}_{2}{ }^{(2)} \mathrm{r}^{3} \vec{\nabla}\left(\mathrm{x} / \mathrm{r}^{3}\right)\right] .
$$

The sphere is located at the origin and is assumed to oscillate in the 
$x$-direction with unit amplitude; the corresponding boundary condition yields

$$
\begin{aligned}
& A_{\mathrm{L}}=-\frac{\left(3+3 i h a-h^{2} a^{2}\right) k^{3} a^{3} \exp (i k a)}{k^{2} a^{2}(1+i h a)+\left(2+2 i k a-k^{2} a^{2}\right) h^{2} a^{2}} \\
& B_{1}=\frac{\left(3+3 i k a-k^{2} a^{2}\right) h^{3} a^{3} \exp (i h a)}{3\left[k^{2} a^{2}(1+i h a)+\left(2+2 i k a-k^{2} a^{2}\right) h^{2} a^{2}\right]}
\end{aligned}
$$

Here, with material density $\rho$, we have

$$
k^{2}=\rho \omega^{2} /(2 \mu+\lambda), \quad h^{2}=\rho \omega^{2} / \mu
$$

where for a lossy material,

$$
\mu=\mu_{1}+i \omega \mu_{2}=\mu_{1}\left(1+\delta_{S}\right), \quad \lambda=\lambda_{1}+i \omega \lambda_{2}=\lambda_{1}\left(1+\delta_{\mathrm{L}}\right),
$$

$\omega \mu_{2} / \mu_{1} \equiv \delta_{\mathrm{S}}$ and $\omega \lambda_{2} / \lambda_{1} \equiv \delta_{\mathrm{L}}$ being shear and compressional loss factor, respectively. Then Young's modulus is $\mathrm{E}=\mathrm{E}^{\prime}\left(1+i \delta_{S}\right) \equiv 3 \mu, \mathrm{E}^{\prime} \cong 3 \mu_{1}$.

The radiation impedance $z=F / i \omega$ was calculated analytically [9] from the $\mathrm{x}$-component of the force acting on the sphere considering the stress $p_{i j}$,

$$
F=2 \pi a^{2} \int p_{r 1} \sin \vartheta d \vartheta ;
$$

our measurements actually refer to $F / \ddot{x}$ or $z / i \omega$. This experimental result fitted to the analytical expression for $\mathrm{Z} / \mathrm{i} \omega$ yielded the values of columns 2 and 3 in Table $I$.

\section{EXTENSIONS OF THE MODEL}

Although the quoted experimental comparisons for viscoelastic media, as well as von Gierke's corresponding measurements on living human tissue [5] had led to good results and thus verified the model and Oestreicher's impedance formula [9], the model obviously still lacks realism as it neglects the upper (free) and lower (rigid) boundary of the slab-shaped viscoelastic specimen. These effects are currently being included by us based on the concept of image sources (spheres). Taking both boundaries into account leads to an infinite number of image sources. For the simpler case of one rigid-halfspace boundary a distance $d$ below the center of the sphere, with an image sphere centered around the distance $2 \mathrm{~d}$ further below, the compressional solutions becomes from Eq. (Ia):

$$
\vec{s}_{1}=-\mathrm{A}_{1} \vec{\nabla}\left[(\mathrm{x}-\mathrm{d}) \mathrm{h}_{1}{ }^{(2)}\left(\mathrm{k} r_{+}\right) / \mathrm{k} r_{+}\right]+\mathrm{A}_{1} \vec{\nabla}\left[(\mathrm{x}+\mathrm{d}) \mathrm{h}_{1}{ }^{(2)}\left(\mathrm{k} r_{-}\right) / \mathrm{k} r_{-}\right]
$$

where $r_{ \pm}=\left[(x \pm d)^{2}+y^{2}+z^{2}\right]^{1 / 2}$, and similarly for $\vec{s}_{2}$. The radiation impedance $z$ can be calculated from Eq. (5) at the place of the test sphere, taking the field of the image sphere into account. 


\section{REFERENCES}

[1] Timoshenko S., Theory of Elasticity (McGraw Hill, New York, 1934).

[2] Roesler F. C., Proc. Phys. Soc. London 69B (1956) 55.

[3] Mooney H. M., Bull. Seismol. Soc. Am. 64 (1974) 473.

[4] Bedding R. J. and Willis J. R., J. Elasticity 3 (1973) 289.

[5] von Gierke H. E., Oestreicher H. L., Franke E. K., Parrack H. O., and von Wittern W. W., J. Appl. Physiology 4 (1952) 886.

[6] Madigosky, W., Fiorito, R., and Überall H., J. Acoust. Soc.Am. 94 (1993) 1780 .

[7] Madigosky W. and Lee G., J. Acoust. Soc. Am. 73 (1985) 1374.

[8] The Dynaliser, Barco Automation Inc., Charlotte NC (1990).

[9] Oestreicher H. L., J.Acoust. Soc. Am. 23 (1951) 707. 